\title{
Small bowel transplantation: Current clinical status
}

\author{
DAVID SIGALET, MD, PHD, FRCSC
}

D SIGALET. Small bowel transplantation: Current clinical status. Can J Gastroenterol 1991;5(4):154-160. With recent refinements in immunosuppression techniques, the first successful reports of small bowel transplantation in humans have now been made, increasing interest in bowel transplantation among clinicians and patients alike. This article reviews recent developments in understanding of the functional capabilities and requirements for effective immune suppression in bowel transplantation. Both experimental and clinical experience with transplantation are discussed, as are the areas which appear to offer the most promise for future developments. Finally guidelines for consideration of patient selection for this procedure are reviewed.

Key Words: Cyclosporine, Immune suppression, Nutrient uptake

\section{Transplantation de l'intestin grêle: État clinique présent}

RESUME: Grâce aux tout derniers progrès des traitements immunosuppresseurs, on rapporte les premières transplantations réussies du grêle chez l'homme, et l'intérêt suscité par cette intervention augmente tant chez les cliniciens que chez les patients. Le présent article passe en revue l'évolution récente des connaissances portant sur les capacités fonctionnelles ainsi que les modalités d'une suppression immunitaire efficace dans la transplantation de l'intestin. L'auteur évoque l'expérience clinique et expérimentale à la fois, et présente les domaines qui sembleraient les plus prometteurs. Finalement, certains critères de sélection des receveurs sont examinés.

Department of Surgery, University of Alberta, Edmonton, Alberta

Correspondence and reprints: Dr D Sigalet, Department of Surgery, Montreal Children's Hospital, 2300 Tupper, Montreal, Quebec H3H IP3. Telephone (514) 934-4400, Fax (514) 934-4341

Received for publication March 28, 1991. Accepted July 17, 1991
$\mathrm{T}$ HE SHORT BOWEL SYNDROME that results from massive losses of small bowel continues to be a difficult problem despite the common use of long term total parenteral nutrition (TPN). TPN is expensive (1), limits the lifestyle of the patient and the patient's family (2), and requires continued long term venous access. Long term TPN in children is even more problematic, with increased nutrient requirements, difficulty with patient compliance, and the risk of associated liver damage, especially in the very young infant (3). Because of these factors, the lifelong mortality from direct complications of long term TPN in the pediatric age group exceeds $15 \%$ (4). In the neonate, massive resection of the small bowel most commonly results from such conditions as necrotizing enterocolitis, malrotation with volvulus, and strangulated abdominal wall defects (4). In the adult population, massive bowel resection most commonly results from mesenteric vascular accidents, inflammatory bowel disease and trauma $(5,6)$. These conditions 
result in a stable incidence of new patients who require long term nutritional support.

Small bowel transplantation as a treatment for short bowel syndrome has been considered for many years, but only in the past year have successful attempts at bowel transplantation been reported $(7,8)$. Inevitably, such results provoke inquiry from patients and families about the applicability of such new therapies to their own situation. Since the last major reviews of small bowel transplantation were published, much new information has been presented $(9,10)$. This article will summarize the research which has led to the success of the cases reported, the current status of bowel transplantation for treatment of short bowel syndrome, and possible directions that future developments may take.

\section{EXPERIMENTAL TECHNIQUES AND MODELS}

Transplantation of vascularized organs, including the bowel, was first attempted by the French surgeon Alexis Carrel (11). The problem of rejection was soon recognized, and interest languished until the late 1950s, when Lillehei's group (12) in Minnesota investigated the effects of ischemia on gut organs. They found that cooling and perfusion with heparinized saline would allow reliable preservation of the small bowel for $4 \mathrm{~h}$; this preserved bowel could be re-implanted and would function indefinitely as an autograft (12). Their model consisted of a one stage operation; the superior mesenteric vessels were isolated, clamped and divided, and the bowel was flushed and then revascularized using the mesenteric vessels of a similarly prepared recipient, re-establishing bowel continuity using end-to-end anastomosis of the native duodenum and ileum to the graft. They also used isolated loops of bowel placed in the neck, permitting the study of immunosuppressive agents and graft function in a controlled fashion such that rejection of the graft would not lead to the death of the animal (13). They had no success with allografts, and with others found minimal survival ad-

TABLE 1

Experimental models of intestinal transplantation

\begin{tabular}{|c|c|c|c|}
\hline Model & & $\begin{array}{l}\text { Immuno- } \\
\text { suppression }\end{array}$ & Outcome (reference) \\
\hline Rat: & Syngeneic & Nil & Indefinite survival (22) \\
\hline Rat: & Fully allogeneic & Nil & Rejection, death at day 14 (22) \\
\hline Rat: & GVHD only possible & Nil & GVHD, death at day $14(40)$ \\
\hline Rat: & Fully allogeneic & CsA $15 \mathrm{mg} / \mathrm{kg} / \mathrm{day}$ & Indefinite survival (22) \\
\hline Dogs: & Fully allogeneic & Nil & Rejection, death at day $12(17)$ \\
\hline Dogs: & Fully allogeneic & CsA $25 \mathrm{mg} / \mathrm{kg} /$ day & $\begin{array}{l}91 \text { days average survival (only } \\
\text { three of } 11 \text { survived longer than } \\
60 \text { days) (17) }\end{array}$ \\
\hline Pig: & Fully allogeneic & CsA $15 \mathrm{mg} / \mathrm{kg} /$ day & $\begin{array}{l}121 \text { days average survival } \\
\text { (indefinite survival in seven of } 16 \text { ) } \\
\text { (39) }\end{array}$ \\
\hline
\end{tabular}

CsA Cyclosporine: GVHD Graft-versus-host disease

vantage using the immunosuppressants available at that time - azathioprine and steroids (14-16).

The dog model was used to evaluate the rejection process in detail, and after the introduction of cyclosporine in the 1970s, the orthotopic model of bowel transplantation in the dog was the first used to assess the effects of cyclosporine on small bowel transplantation (17, 18). The significant prolongation of graft survival demonstrated by Reznick et al $(17,18)$ from Toronto in a landmark study was encouraging, but the overall success rate was low (further details are discussed in the section on immunosuppression).

The description of heterotopic bowel transplantation in the rat by Monchik and Russell in 1971 (19) greatly facilitated study in this field. The rat model has since served as the standard for initial investigations of immunosuppression, function and techniques. Technically, the procedure is similar to that described for larger animals, the main problem being the small size of the vessels. The aorta is used as the conduit for the superior mesenteric artery, and the graft is revascularized using the recipient's inferior vena cava and aorta. The bowel is left as a Thiry-Villa fistula with proximal and distal stomas (heterotopic graft). Initial attempts to re-establish gastrointestinal continuity immediately using the graft were plagued with a high failure rate (20); however, with experience this improved $(21,22)$. This model then became the standard for investigation of small bowel transplantation in rats. Within the rat model the availability of genetically defined strains of animals has greatly facilitated investigation of the immunological consequences of small bowel transplantation $(18,23)$. The current availability of monoclonal antibodies to various cell populations in the rat should provide further valuable information.

The pig is an excellent model of human bowel physiology, with a more defined genetic lineage than the dog (24). Although earlier attempts had been made (25), Ricour and colleagues (26) were the first to perform successful small bowel transplantation in the pig and achieve allograft survival. The techniques used paralleled those used in the dog.

In reviewing reports of experimental models of small bowel transplantation, one must remember that rejection responses and function vary considerably depending on the model. Inbred strains of rats have varying rejection responses, while outbred larger animals generally undergo a more vigorous reaction $(13,19,25)$. Similarly, different models within the same species may exhibit different rejection responses: grafts drained via the portal circulation of the recipient may have a survival advantage, while caval drainage permits more vigorous rejection $(27,28)$. This may be due to an effect of the liver on soluble antigen processing: liver transplantation has long been known to permit the survival of subsequent grafts from the same 
donor, with normal rejection of 'third party' grafts $(29,30)$. Finally, graft survival in heterotopic models does not imply that the graft is necessarily capable of supporting the animal nutritionally.

\section{REJECTION AND GRAFT- VERSUS-HOST DISEASE}

The histology of small bowel allograft rejection has been well described, and can be divided into three phases $(19,31)$. In the rat at day 3 , there is no change detectable with routine light microscopy, but at days 6 and 7, lymphocytes and plasma cells begin to infiltrate the lamina propria. In phase II, over days 8 and 9 , the infiltrate intensifies and extends to the muscularis propria. There is associated shortening and blunting of the villi and scattered epithelial sloughing. In phase III, which occurs after the 10th day, there is complete mucosal destruction and transmural infiltration with lymphocytes and polymorphonuclear leukocytes. Rejection is similar in dogs and pigs, but has an accelerated time course; rejection is complete by days 7 to $9(12-14,26)$.

The small bowel is unique among transplanted vascularized organs because of the large population of immunocompetent cells which can become activated following transplantation into a non-major histocompatibility complex (MHC) identical recipient. This leads to a phenomenon known as 'graft-versus-host disease', initially described following bone marrow transplantation. This problem was recognized by the early investigators of small bowel transplantation (12), and examined in detail using inbred strains of rats (19). When both rejection and graft-versus-host disease are possible, rejection is the dominant response; however, when animals are treated with potent immunosuppressants such as cyclosporine, graft-versus-host disease becomes important. This results in an activation of graft-derived $\mathrm{T}$ cells directed against cell surface antigens of host epidermal cells (possibly primitive stem cell markers [32]). The disease complex seen after small bowel transplantation is a phase of poor appetite, red ears and snout, diarrhea, weight loss and hunched posture, from which most animals recover spontaneously (33). There may be differences in the intestinal manifestations of the graft-versushost disease seen after small bowel versus bone marrow transplantation (34); this possibility requires further investigation.

\section{REJECTION MONITORING}

In the clinical setting it is important to monitor for rejection. The nonspecific nature of the early stages of acute rejection noted above were found to limit the usefulness of suction biopsy in monitoring for rejection in the one clinical case that has been well documented $(35,36)$. This problem, coupled with the difficulty and possible hazards of obtaining biopsy material, have prompted investigators to search for alternate methods of monitoring for rejection. The functional capacity of the bowel has been exploited; the best characterized of these markers is the maltose absorption test (37). This test measures the ability of the bowel mucosa to split maltose into glucose and then transport it across the enterocyte into the circulation, where it is detected by monitoring of serum glucose levels. The resulting rise is diminished when rejection is in the initial stages.

A simpler method monitors changes in the permeability of the bowel wall by measuring the urinary excretion of chromium-51 EDTA instilled in the lumen of the graft. The bowel is normally impervious to this compound; an increase in absorption occurs with early graft rejection (38). This test has been used clinically and has been found to correlate well with biopsy evidence of rejection (7).

\section{METHODS OF IMMUNOSUPPRESSION}

At present, the factor which limits the use of small bowel transplantation clinically is the lack of a reliable protocol for immunosuppression. After the description of the surgical techniques required for successful small bowel transplantation in dogs, a number of different immunosuppressants were used, with limited success. These included steroids, azathioprine, antilymphocyte globulin and graft irradiation $(14-16,39)$. It was not until the introduction of cyclosporine in the late 1970s that a significant prolongation of small bowel allograft survival was achieved (17). The average survival in 11 dogs treated with cyclosporine (25 $\mathrm{mg} / \mathrm{kg} /$ day, intramuscular injection for the first 28 days, then oral administration) was 91 days, while untreated controls survived an average of 12.5 days. However, it is important to note that only three dogs survived more than 60 days, and two of these succumbed to rejection at 210 days. The importance of using parenteral cyclosporine was demonstrated in a follow-up study from the same group, in which a third set of animals was given oral cyclosporine: seven of 10 died of acute rejection an average of 30 days post transplant (18).

Once it had been shown that cyclosporine prolonged the survival of intestinal allografts in dogs, a series of studies in the more controlled rat model appeared. A dosage of cyclosporine of $15 \mathrm{mg} / \mathrm{kg} /$ day allowed indefinite survival of grafts in unidirectional and two-way rejection and graft-versushost disease models (22). A similar dosage of cyclosporine was also shown to control graft-versus-host disease (40).

The model of bowel transplantation available which most closely resembles the situation in humans is the pig. Monotherapy with high dosage intravenous cyclosporine $(15 \mathrm{mg} / \mathrm{kg} /$ day $)$ for 10 days post transplant, followed by continued high dosage oral therapy ( 30 $\mathrm{mg} / \mathrm{kg} /$ day), has allowed successful transplantation in this model (41). These high dosages seem necessary: protocols using lower doses have an in. creased rate of animal death, although this has not been shown to be due to rejection (42). In the pig, combined steroid and cyclosporine use increased the rate of infectious complications and did not reduce the rate of rejection (41), while graft irradiation was not useful (43). It is interesting to note that stopping cyclosporine after two to three months of continuous therapy did not lead to allograft rejection (41). The 
recipient may develop tolerance to the bowel allograft in a fashion similar to that described for liver transplants (29).

A tremendous effort is underway to improve methods of immunosuppression (44). These methods have in large part focused on pharmacological control of rejection post transplantation. The new drugs FK506, rapamycin and 15-deoxyspergualin have already been shown to allow successful small bowel transplantation in rat models, and are currently being reviewed in large animal and human studies (45-47). Alternative strategies, such as pretreatment of graft with monoclonal antibodies (48) or of host with donorspecific transfusion, are also useful experimentally (49). The challenge at present will be to develop effective combined strategies which optimize both pretreatment of donor and recipient, and post transplantation immunosuppression.

\section{FUNCTION OF TRANSPLANTED BOWEL}

In the first studies of small bowel transplantation Lillehei and coworkers (12) showed that animals could survive indefinitely following autotransplantation. No specific study of nutrient absorption was performed, but gross malabsorption of fat was evident for two to three weeks, and then subsided. They were also able to demonstrate regeneration of severed lymphatics after three weeks (50). More detailed studies demonstrated that, following transplantation of the small bowel, dogs had a period of two to three weeks of diarrhea, weight loss and abnormal motility with steatorrhea. These changes reversed over the ensuing months; by six months function had normalized (51). An identical pattern of changes could be produced by denervating the bowel and dividing the lymphatics; it was concluded that the functional alterations of transplantation observed were due to denervation and lymphatic disruption, and were reversible.

Several investigators have shown that the transplanted bowel becomes electrically autonomous, and that this may result in a reduction in glucose, glycine, water and sodium absorption $(52,53)$. Chloride is most significantly affected, with a net secretion in some instances, possibly due to a loss of the normal inhibition of crypt chloride secretion by the autonomic nervous system following small bowel transplantation. Limited studies of bowel function at the enterocyte level have been published: the electrophysiological parameters of the bowel seem normal at nine days post transplant but deteriorate rapidly if rejection occurs (23).

In animals that are nutritionally dependent on a small bowel transplant, long term reductions in fat, protein and carbohydrate absorption have been demonstrated (54-56). Cyclosporine itself may also affect nutrient absorption. Preliminary evidence suggests that cyclosporine reduces glucose, alanine and fatty acid uptake in normal rats, and in autografted bowel in dogs $(56,57)$. Overall, these findings suggest that both the transplantation process itself and rejection (if it occurs) significantly affect the motility, neural and transport functions of small bowel. When the major portion of the small bowel is transplanted, recipient growth is near normal in most models $(22,41)$; however, the length required to sustain the recipient post transplant has not been determined. Given the present interest in trials of bowel transplantation in humans, this area requires further investigation.

\section{CLINICAL EXPERIENCE}

All attempts at small bowel transplantation in humans prior to the introduction of cyclosporine were unsuccessful. The longest survivor lived for 76 days; even with a human lymphocyte antigen (HLA) identical donor and (delayed) treatment with steroids, azathioprine and antilymphocyte globulin, rejection and overwhelming sepsis from enteric flora proved fatal (58). Other attempts were equally disappointing $(8,59,60)$. Following the success of small bowel transplantation using cyclosporine in dogs and pigs, a number of attempts at human transplantation have been reported $(8,35,61-63)$. The results have been poor. Typically, rejection is seen in graft biopsies four to 10 days post transplant. Bowel fluid losses increase tremendously. Steroids and antilymphocyte globulin have diminished the rejection response $(35,61)$, but rejection has usually progressed, necessitating graft removal around the 15 th day post transplant. Pretreatment of the graft with OKT3 antibody has not reduced the apparent immunogenicity of the bowel $(8,35)$. Rejection has occurred despite portal drainage of the graft, but most patients requiring bowel transplantation have either a thrombosed portal vein or multiple previous operations prohibiting an anastomosis to the portal circulation (8-10). Cyclosporine regimens reported have included intermittent and continuous infusion (35,61-63) with levels of cyclosporine that are therapeutic for kidney and liver transplants (200 to $400 \mathrm{ng} / \mathrm{mL}$ in whole blood radioimmunoassay [64]). Toxicity of immunosuppression has been a common problem; cyclosporine has resulted in renal toxicity $(8,61)$, while combined therapy (steroid, antilymphocyte globulin and azathioprine) has resulted in infectious complications $(8,35,62)$. Children receiving bowel as part of a graft of multiple viscera have developed lymphoproliferative disorders (65, 66). Clearly, these case reports demonstrate that, with the current state of immune therapy, immune suppression following isolated small bowel transplantation remains a difficult problem. If a very close HLA match can be achieved, it may be possible to control rejection more effectively (58); however, this has not been demonstrated in an animal model.

As noted earlier, in consideration of the possible advantages of portal drainage, liver transplantation reduces rejection of co-transplanted grafts. This may be by nonself antigen processing by the liver or release of soluble MHC antigens which then block cytotoxic ant $\mathrm{i}$ bodies (30). In clinical transplantation, improved survival of renal grafts following liver transplantation has been clearly documented, even in the presence of preformed antibodies to the 
graft (67). In addition to this, anatomical considerations had defined the concept of a multivisceral transplant or 'cluster operation' for combined liver and pancreaticoduodenal pathology $(65,66)$. A complete visceral transplant - including stomach, liver, pancreas and various lengths of bowel - can be performed for extensive celiac pathology. In this situation, standard immunosuppressive therapy with cyclosporine, prednisone and antilymphocyte globulin have allowed prolonged survival of the associated bowel $(65,66)$. It seemed logical to extend this to include a combined small bowel and liver graft for short bowel syndrome with associated primary liver disease, as reported by Grant (7). Grant described a typical immunosuppressive protocol for isolated liver transplantation which has prevented rejection in the as-

ACKNOWLEDGEMENTS: This work was supported by the Alberta Heritage Foundation for Medical Research clinical fellowship \#12-609. The author acknowledges the helpful comments of Norman Kneteman, MD, Alan BR Thomson, MD, and Richard Fedorak, MD. The secretarial assistance of Susan Evans-Davies is gratefully appreciated.

\section{REFERENCES}

1. Wateska LP, Sattler LL, Steiger E. Cost of a home parenteral nutrition program. JAMA 1980;244:2303-4.

2. Perl M, Hall RCW, Dudrick SJ, et al. Psychological aspects of long-term home hyperalimentation. JPEN 1980;4:554.

3. Hodes JE, Grosfeld JL, Weber TR, et al. Hepatic failure in infants on total parenteral nutrition: Clinical and histopathologic observations. J Pediatr Surg 1982:17:463-8.

4. Grosfeld JL, Rescoria FJ, West KW. Short bowel syndrome in infancy and childhood. Analysis of survival in 60 patients. Am J Surg 1986;151:41-6.

5. Tilson MD. Pathophysiology and treatment of short bowel syndrome. Surg Clin North Am 1980;60:1273-84.

6. Sigalet DL, Thomson ABR. Consequences of small bowel resection. Med Clin North Am 1988;18:3423-32.

7. Grant D, Wall W, Mimeault R, et al. Successful small-bowel/liver transplantation. Lancet sociated bowel in three patients to date (7, personal communication).

Although initial experience with the cluster operation was entirely clinical and no major problem with rejection of the associated bowel was reported, an experimental study in rats has shown that the cluster operation does not 'protect' the associated bowel (68). However, there are no experimental data dealing specifically with the issue of combined small bowel and liver transplantation. Clinical success already achieved certainly justifies continued interest in this area. Whether or not a person with short bowel syndrome and no associated liver disease should receive a combined liver-small bowel graft, in hopes that the liver will reduce the immunogenicity of the bowel graft, remains to be seen. The survival of patients receiving an iso-

\section{0;335:181-4}

8. Schroeder P, Goulet O, Lear PA. Small bowel transplantation: European experience. Lancet 1990;335:110-1.

9. Schraut WH. Current status of small bowel transplantation. Gastroenterology 1988;94:525-38.

10. Watson AJM, Lear PA. Current status of intestinal transplantation. Gut 1989;30:1771-82.

11. Carrel A. La technique opératoire des anastomoses vasculaires et la transplantation des viscères. Lyon Med 1902;98:859-64

12. Lillehei RC, Goott B, Millaer FA The physiological response of the small bowel of the dog to ischemia including prolonged in vitro preservation of the bowel with successful replacement and survival. Ann Surg 1959;150:542-60.

13. Lillehei RC, Idezuki Y, Reemster JA, et al. Transplantation of stomach, intestine and pancreas: Experimental and clinical observations. Surgery 1967:62:721-41.

14. Preston FW, Macalalad P, Wachowski TJ, Randolph DA, Apostol JV. Survival of homografts of the intestine with and without immunosuppression. Surgery 1966;60:1203-10.

15. Taylor RMR, Watson JW, Walker FC, Watson AJ. Prolongation of survival of jejunal homografts in dogs treated with azathioprine (Imuran). Br J Surg 1966;53:134-8.

16. Hardy MA, Quint J, Stale D. Effect of antilymphocyte serum and other immunosuppressive agents on canine jejunal allografts. Ann Surg 1970;171:51-60. lated liver graft for primary liver disease (over 70\% five year survival [69]) demonstrates that the liver transplant portion of a combined liver-small bowel transplantation would be unlikely to harm the recipient. Selected patients with life-threatening complications of short bowel syndrome and primary liver disease can ethically be considered for such therapy (70). With short bowel syndrome alone (and lifethreatening complications which prevent combined support with TPN), isolated small bowel transplantation could be considered (8). Given the complexities of the technical and immunological aspects of the procedure, the preliminary work should be concentrated in a few experienced centres. Ongoing evaluation of the results will permit an accurate assessment of the risk/benefit ratio of this procedure (70).

17. Reznick RK, Craddock GN, Langer B, Gilas T, Cullen JB. Structure and function of small bowel allografts in the dog: Immunosuppression with cyclosporin A. Can J Surg 1982;25:51-5.

18. Craddock GN, Nordgren SR, Reznick RK, et al. Successful small bowel transplantation in the dog using cyclosporine. Transplantation 1983;35:284-8.

19. Monchik GJ, Russel PS. Transplantation of small bowel in the rat: Technical and immunological considerations. Surgery 1971;70:693-702.

20. Kort WJ, Westbroeck DL, MacDicken I, Lameijer LDF. Orthotopic total small-bowel transplantation in the rat. Eur J Surg Res 1973;5:81-9.

21. Preissner WCh, Schroeder P, Gundlach M, et al. Microsurgical techniques of heterotopic and orthotopic small-bowel transplantation in the rat. In: Deltz E, Thiede A, Hammelmann H, eds. Small-Bowel Transplantation. Experimental and Clinical Fundamentals. Heidelberg: Springer-Verlag, 1986:2-13.

22. Lee KKW, Schraut WH. Structure and function of orthotopic small-bowel allografts in rats with cyclosporine $\mathrm{A}$. Am J Surg 1986;151:55-60.

23. Kirkman RL, Lear PA, Madara JL, Tilney NL. Small intestine transplantation in the rat Immunology and function. Surgery 1984;96:280-7.

24. Sigalet DL, Lees GM, Aherne FX, et al. The physiology of adaptation to 
small bowel resection in the pig: An integrated study of morphological and functional changes. J Pediatr Surg 1990;25:650-7.

25. Stauffer UG, Becker M, Hirsig J, Meier HP, Kara O. The risks of small intestinal transplantation for the recipient: Experimental results in young minipigs. J Pediatr Surg 1978;13:465-7.

26. Ricour C, Revillon Y, ArnaudBattandier F, et al. Successful small bowel allografts in piglets using cyclosporine. Transplant Proc 1984:15:3019-23.

27. Sakai A. Role of the liver in kidney allograft rejection in the rat. Transplantation 1970;9:333-8.

28. Schraut WH, Abraham VS, Lee KKW. Portal versus systemic venous drainage of small-bowel allografts. Surgery 1985;98:579-85.

29. Kamada N, Davies HS, Wight D, Culank L, Roser B. Liver transplantation in the rat. Biochemical histological evidence of complete tolerance induction in non-rejector strains. Transplantation 1983;35:304-11.

30. Astarcioglu I, Gugenheim J, Gigou M, et al. Immunosuppressive properties of auxiliary liver-allografts into sensitized rats. Transplantation 1990;49:1 186-8.

31. Rosemurgy AS, Schraut WH. Small bowel allografts. Sequence of histologic changes in acute and chronic rejection. Am J Surg 1986;151:470-5.

32. Ferrara JLM, Deeg JH. Graft versus host disease. N Engl I Med 1991;324:667-74.

33. Diflo T, Maki T, Balogh K, Monaco AP. Graft-versus-host disease in fully allogeneic small bowel transplantation in the rat. Transplantation 1989:47:7-11.

34. Wallander J, Scheynius A, Lackgren G, Tufveson G. Immunomorphology of graft versus host disease after small bowel transplantation in the rat. Scand J Immunol 1990;32:93-101.

35. Grant D, Sommerauer J, Mimeault R, et al. Treatment with continuous high-dose intravenous cyclosporine following clinical intestinal transplantation. Transplantation 1989:48:151-2.

36. Milliard PR, Dennison A, Hughes DA, Collin J, Morris PJ. The morphology of intestinal allograft rejection and the inadequacy of mucosal biopsy in its recognition. $\mathrm{Br}$ ] Exp Pathol 1986;67:687-98.

37. Billiar TR, Garberoglio C, Schraut W Maltose absorption as an indicator of small-intestinal allograft rejection. J Surg Res 1984;37:75-82.

38. Grant D, Lamont D, Zhang R, et al. ${ }^{51} \mathrm{Cr}$-EDTA: A marker of early intestinal rejection in the rat. I Surg Res 1989;46:507-14.

39. Cohen Z, MacGregor A, Moore KTH, Falk RE, Langer B, Cullen JB. Canine small bowel transplantation. A study of immunological responses. Arch Surg 1976;111:248-53.

40. Deltz E, Ulrichs K, Schack T, et al. Graft versus host reaction in small intestine transplantation and possibilities for its circumvention. Am J Surg 1986;151:379-86.

41. Grant D, Duff J, Zhong R, et al. Successful intestinal transplantation in pigs with cyclosporin. Transplantation 1988;45:279-84.

42. Kimura K, LaRosa LA, Blank M, Jaffe $B M$. Successful segmental intestinal transplantation in enterectomized pigs. Ann Surg 1990;211:158-64

43. Grant D, Duff J, Zhong R, Mimeault R, Inch R, Stiller C. Effect of ex vivo allograft irradiation combined with cyclosporine therapy in a pig intestinal transplant model. Transplant Proc 1989;21:2879-80.

44. Kahan BD. Transplantation timeline; mankind's three millennia-One maverick's three decades in the struggle against biochemical individuality. Transplantation 1991;51:1-21.

45. Hoffman AL, Makowka L, Banner B, et al. The use of FK-506 for small intestine allotransplantation. Transplantation 1990;49:483-90.

46. Stepkowski S, Chen H, Daloze P, Kahan BD. Rapamycin, a potent immunosuppressive drug for vascularized heart, kidney, and small bowel transplantatian in the rat. Transplantation 1991;51:22-6.

47. Iga C, Okajima K, Takeda Y, Tezuka $K$. Prolonged survival of small intestinal allograft in the rat with cyclosporine A, FK506 and 15-deoxyspergualin. Transplant Proc 1990:22:1658.

48. Shaffer D, Simpson MA, Milford EL, et al. Donor pretreatment with monoclonal antibody for prevention of graft-versus-host disease following small bowel transplantation. Effect of depletion of t-cell subsets. Transplant Proc 1991;23:679-81.

49. Martinelli GP, Knight RK, Kaplan S, et al. Small bowel transplantation in the rat; effect of pretransplant blood transfusion and cyclosporine on host survival. Transplantation 1988;45:1021-6.

50. Goott B, Lillehei RC, Miller FA. Mesenteric lymphatic regeneration after autografts of small bowel in dogs. Surgery 1960;48:571-5.

51. Ballinger WF, Christy MG, Ashby WB. Autotransplantation of the small intestine: The effect of denervation.
Surgery 1962:52:151-64.

52. Sarr MG, Duenes JA.

Autotransplantation of the entire jejunoileum in dogs: Effects on jejunal and ileal absorptive functions. Gastroenterology 1989;96:A441.

53. Watson AJM, Lear PA, Montgomery A, et al. Water, electrolyte, glucose and glycine absorption in rat small intestinal transplants.

Gastroenterology 1988;94:863-9.

54. Raju S, Fujiwara H, Grogan JB, Achord JL. Long-term nutritional function of orthotopic small bowel autotransplants. J Surg Res 1989;46:142-6.

55. Schraut WH, Lee KKW, Sitrin M Recipient growth and nutritional status following transplantation of segmental small-bowel allografts. J Surg Res 1987:43:1-9.

56. Collin J, Dennison AR, Watkins RM, Milliard PR, Morris PJ. Segmental small intestinal allografts II: Inadequate function with cyclosporine immunosuppression: Evidence of a protein-losing enteropathy.

Transplantation 1987:44:479-83.

57. Sigalet DL, Kneteman NM, Thomson ABR. Cyclosporine effects on normal bowel function. Transplantation 1991:51:1296-8.

58. Fortner JG, Sichuk G, Litwin SD, Beattie EJ. Immunological responses to an intestinal allograft with HLA. identical donor-recipient. Transplantation 1972;14:531-5.

59. Alican F, Hardy JD, Cayirli M, et al. Intestinal transplantation: Laboratory experience and report of a clinical case. Am J Surg 1971;121:150-9.

60. Ruiz JO, Lillehei RC. Intestinal transplantation. Am J Protocol 1972;23:379-93.

61. Goulet OJ, Revillon Y, Cerf-Bensussan $\mathrm{N}$, et al. Small intestinal transplantation in a child using cyclosporine. Transplant Proc 1988;20(Suppl 3):288-96.

62. Cohen Z, Silverman R, Levy G, Wassef R, Langer B. Clinical small intestinal transplantation using cyclosporine $\mathrm{A}$ and methylprednisolone. Transplant Proc 1987;19:2588-90.

63. Deltz E, Schroeder P, Gundlach M, Gebhardt H, Hansmon ML, Leimenstoll G. Successful clinical small bowel transplantation. International Symposium on Small Bowel Transplantation, London, 1989.

64. Shaw LM. Advances in cyclosporine pharmacology, measurement and therapeutic monitoring. Clin Chemother 1989;35:1299-308.

65. Williams JW, Sankary HN, Foster PF, Lowe J, Goldman GM. Splanchnic transplantation: An approach to the 
infant dependent on parenteral nutrition who develops irreversible liver disease. JAMA 1989;261:1458-62.

66. Starzl TE, Rowe MI, Todo S, et al. Transplantation of multiple abdominal viscera. JAMA 1989;261:1449-57.

67. Gonwa TA, Nery JR, Husberg BS, Klintmalm GB. Simultaneous liver and renal transplantation in man.

Transplantation 1988;46:690-3.

68. Murase N, Demetris AJ, Kim DG,

Todo S, Fung JJ, Starzl TE. Rejection

of multivisceral allografts in rats:

A sequential analysis with comparison

to isolated small-bowel and liver grafts. Surgery 1990;108:880-9.
69. Rolles K. Summary of clinical data: Liver transplantation. In: Brent L, Selles RA, eds. Organ Transplantation. Current Clinical and Immunological Concepts. London: Baillière Tindall, 1989:201-6.

70. Anon. When surgeons experiment. Lancet 1990;335:199-200. (Edit) 


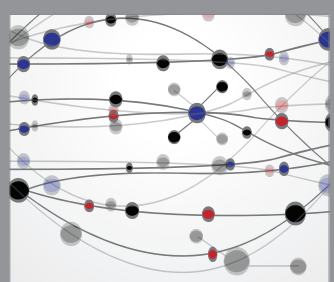

The Scientific World Journal
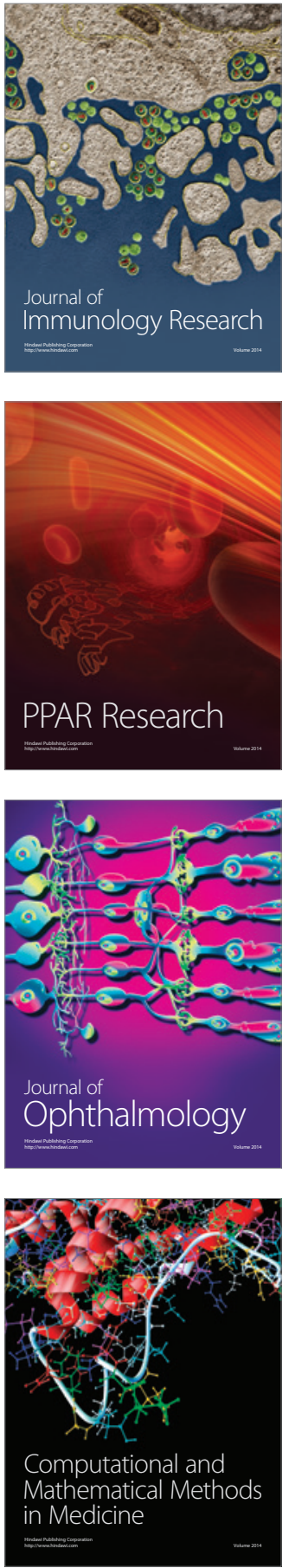

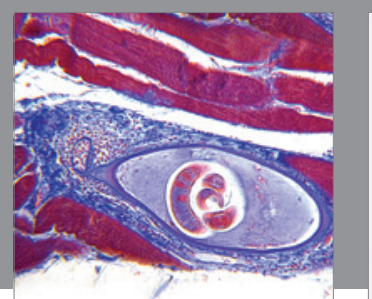

Gastroenterology Research and Practice

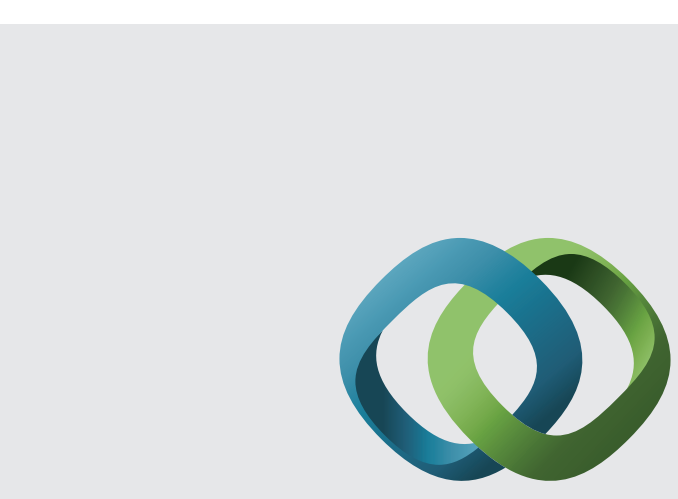

\section{Hindawi}

Submit your manuscripts at

http://www.hindawi.com
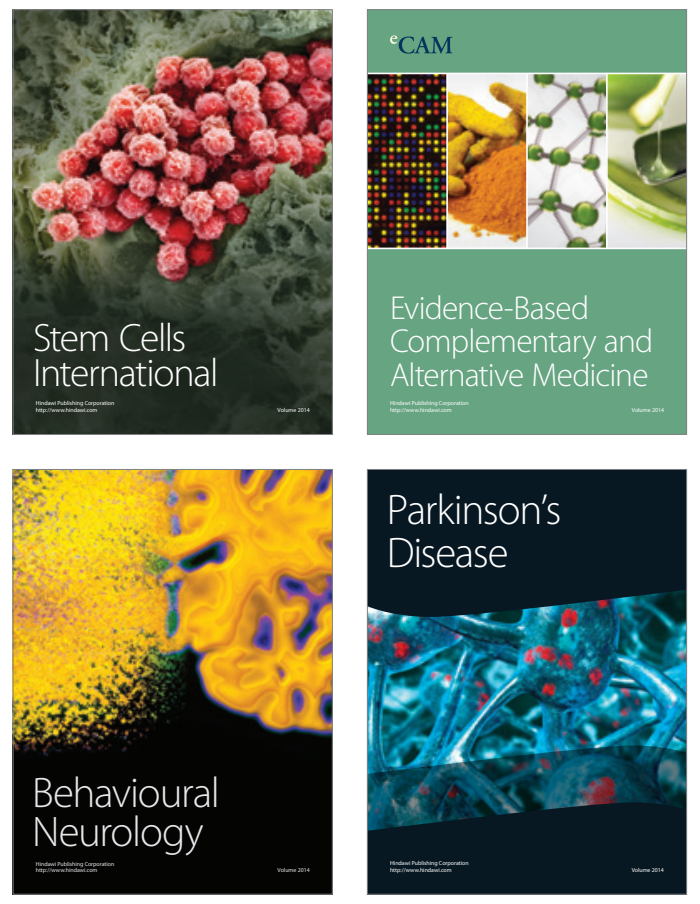
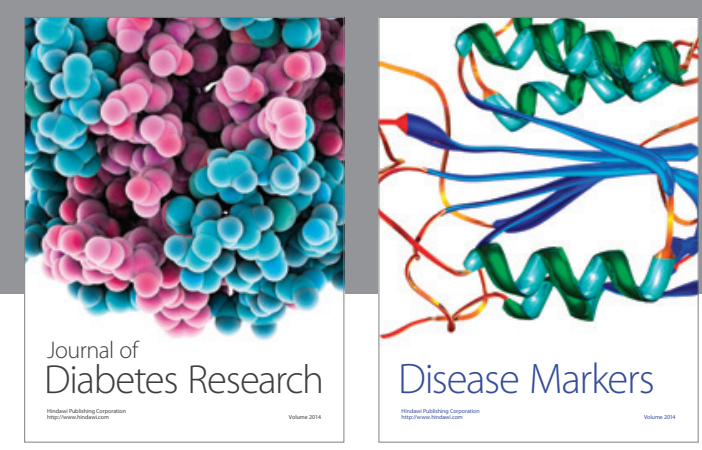

Disease Markers
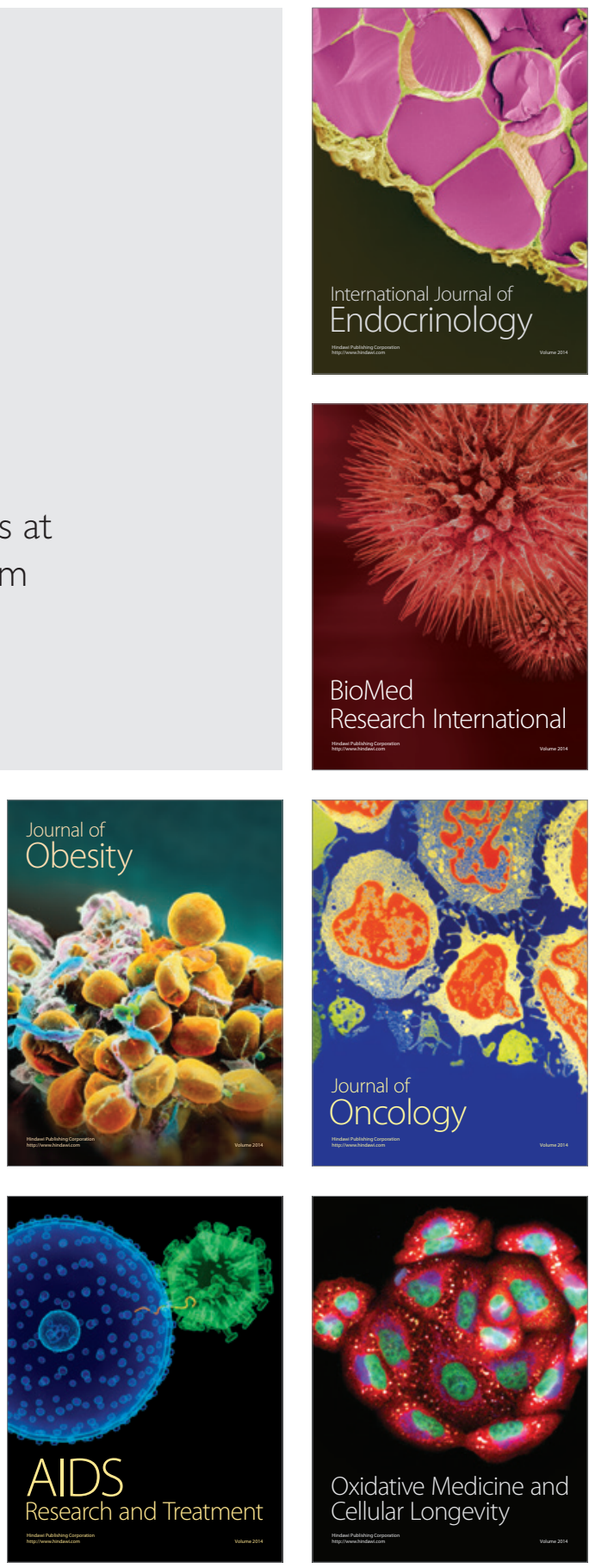